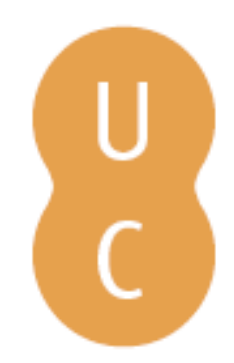

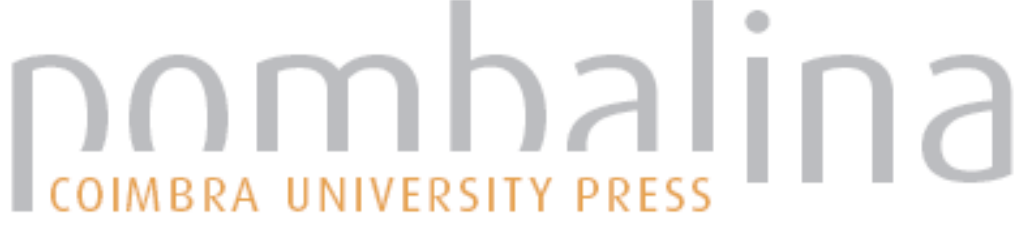

Detritos federais: o vômito e o silenciamento de Lucrécio Barba-de-Bode

Autor(es): $\quad$ Silva, Marcos

Publicado por: Imprensa da Universidade de Coimbra

URL

persistente: URI:http://hdl.handle.net/10316.2/31142

DOI: $\quad$ DOI:http://dx.doi.org/10.14195/978-989-26-0497-8_12

Accessed : $\quad$ 26-Apr-2023 11:14:44

A navegação consulta e descarregamento dos títulos inseridos nas Bibliotecas Digitais UC Digitalis, UC Pombalina e UC Impactum, pressupõem a aceitação plena e sem reservas dos Termos e Condições de Uso destas Bibliotecas Digitais, disponíveis em https://digitalis.uc.pt/pt-pt/termos.

Conforme exposto nos referidos Termos e Condições de Uso, o descarregamento de títulos de acesso restrito requer uma licença válida de autorização devendo o utilizador aceder ao(s) documento(s) a partir de um endereço de IP da instituição detentora da supramencionada licença.

Ao utilizador é apenas permitido o descarregamento para uso pessoal, pelo que o emprego do(s) título(s) descarregado(s) para outro fim, designadamente comercial, carece de autorização do respetivo autor ou editor da obra.

Na medida em que todas as obras da UC Digitalis se encontram protegidas pelo Código do Direito de Autor e Direitos Conexos e demais legislação aplicável, toda a cópia, parcial ou total, deste documento, nos casos em que é legalmente admitida, deverá conter ou fazer-se acompanhar por este aviso.

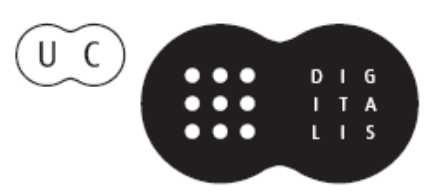


Armando Malheiro da Silva

Maria Luiza Tucci Carneiro

Stefano Salmi

Coordenação

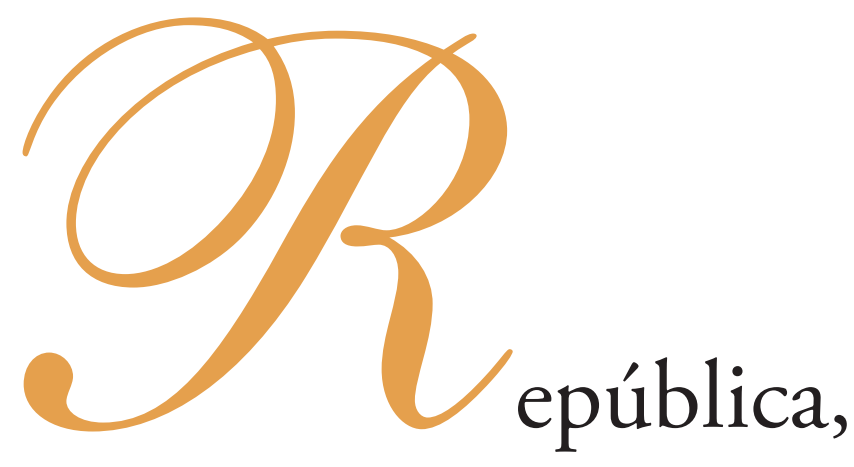

Republicanismo

e Republicanos

Brasil • Portugal • Itália 


\author{
Marcos Silva
}

\title{
DETRITOS FEDERAIS: O VÔMITO E O SILENCIAMENTO DE LUCRÉCIO BARBA-DE-BODE
}

\author{
"A Cidade Nova não teve tempo de acabar de levantar-se \\ do charco que era; (...) mas ficou sendo o depósito dos detritos \\ da cidade nascente, das raças que nos vão povoando e \\ foram trazidas para estas plagas pelos negreiros, \\ pelos navios de imigrantes, à força e à vontade".
}

(LIMA BARRETO, Numa e a ninfa, p 83).

"(...) a nossa ação são as palavras".

(Fala do deputado Pieterzoon, LIMA BARRETO, Numa e a ninfa, p 128).

Lucrécio Barba-de-Bode é personagem do romance Numa e a ninfa, de Lima Barreto $^{378}$. Trata-se de mulato pobre, ex-carpinteiro, desempregado, morador da Cidade Nova, um bairro popular do então Distrito Federal do Brasil - a cidade do Rio de Janeiro. Ele participava da vida política republicana como uma espécie de capanga de poderosos, fazendo serviços "sujos" (ameaças a adversários,

${ }^{378}$ BARRETO, Afonso Henriques de Lima - Numa e a ninfa. São Paulo: Brasiliense, 1961 (Obras de Lima Barreto - III) (1 ${ }^{\text {a }}$ ed. 1915).

Quando comentou o florianismo nesse romance, Lima Barreto evocou indiretamente seu romance anterior: Idem - Triste fim de Policarpo Quaresma. 15 ed.. São Paulo: Brasiliense, 1976 (Obras Completas - II). (1 $1^{a}$ ed. 1915). Ver também o conto anterior: Idem - "Numa e a ninfa". In Histórias e sonhos. São Paulo: Brasiliense, 1956 (1 $1^{\mathrm{a}}$ ed. 1920). 
dissolução de seus comícios etc.), levando e trazendo recados, presente em manifestações a favor de determinados políticos, freqüentemente no limiar da criminalidade, dependente daqueles mandões:

“(...) não era propriamente um político mas fazia parte da política, e tinha o papel de ligá-la às classes populares."

(NN, pp 58/59).

Nas eleições de Bentes (candidato ficcional, em muito semelhante a Hermes da Fonseca - militar de alta patente, ex-Ministro) para a presidência da República,

"A ação de Lucrécio foi onímoda e maravilhosa. Ele destruiu cartazes, apreendeu boletins, apreendeu jornais, desafiou rapazes, e, de onde em onde, dava um tiro de revólver."

(IDEM, p. 244).

Embora a fortuna crítica de Lima Barreto tenha oscilado ao longo do século Xx, esse escritor mereceu a atenção de influentes literatos e intelectuais brasileiros, tanto em vida (Oliveira Lima, João Ribeiro) quanto depois (Mário de Andrade, Otto Maria Carpeaux e Alfredo Bosi). Estudos acadêmicos das últimas décadas mantiveram essa atitude, como o demonstram as teses e dissertações de Maria Zilda Ferreira Cury, Carlos Erivany Fantinati e Nicolau Sevcenko, junto com os trabalhos mais recentes de Idilva Maria Pires Germano, Elizabeth Gonzaga de Lima, Denílson Botelho e Zélia Nolasco Freire ${ }^{379}$. O apreço de ficcionistas por seu

${ }^{379}$ LIMA, Manoel de Oliveira - "Prefácio". In BARRETO, Afonso Henriques de Lima - Triste fim de Policarpo Quaresma, op. cit.; RIBEIRO, João - "Prefácio". In BARRETO, Afonso Henriques - Numa e a ninfa. Edição citada, pp 9/12 (1 $1^{a}$ ed. do texto de Ribeiro: 1917); ANDRADE, Mário de - "A Psicologia em ação". In COUTINHO, Afrânio (Org.) - Caminhos do pensamento crítico. $2^{\mathrm{a}}$ ed. Rio de Janeiro/ Brasília: Palla/INL, 1980, 2 vol.; CARPEAUX, Otto Maria - "Dialética da Literatura brasileira". In FURTADO, Celso (Coord.) - Brasil Tempos Modernos. Rio de Janeiro: Paz e Terra, 19....; BOSI, Alfredo - O Pré-Modernismo. $4^{\mathrm{a}}$ ed. São Paulo: Cultrix, 1973 (A Literatura Brasileira - V); Idem - "As Letras na Primeira República”. In FAUSTO, Boris (dir.) - O Brasil republicano. Sociedade e instituições. Rio de Janeiro/São Paulo: Difel, 1977, pp. 293-319 (História Geral da Civilização Brasileira, tomo III, volume 2); CURY, Maria Zilda Ferreira - Um mulato no Reino de Jambom. São Paulo: Cortez, 1981; FANTINATI, Carlos Erivany - O profeta e o escrivão. São Paulo/Assis: HUCITEC/ILHPA-UNESP, 1978; SEVCENKO, Nicolau Literatura como missão. São Paulo: Brasiliense, 1983; GERMANO, Idilva Maria Pires - Alegorias do Brasil. Fortaleza/São Paulo: Secretaria de Cultura e Desporto do CE/Annablume, 2000; LIMA, Elizabeth Gonzaga de - Avesso de Utopias: Os Bruzundangas e Aventuras do Doutor Bogóloff. Dissertação de Mestrado 
trabalho também não esmoreceu, atestado pelos comentários de João Antonio e Osman Lins ${ }^{380}$.

Numa e a ninfa não costuma ser incluído entre as principais criações de Lima Barreto. O romance se dedicou a episódios da política brasileira do início do século Xx - o personagem que lhe dá título, Numa Pompílio de Castro, é deputado federal e genro de um governador, Neves Cogominho. Faz alusões à sucessão presidencial de Afonso Pena e Nilo Peçanha, particularmente, à ascensão de Hermes da Fonseca como candidato à presidência e sua eleição, incluindo mencionar o espectro do militarismo e as "salvações" políticas em alguns estados. O livro definiu um contraponto entre o universo republicano das elites (Numa e seus pares) e a presença popular nas franjas do sistema político (Lucrécio e seus companheiros de ocupação). São elites endinheiradas, com aparência refinada e erudita, diante de camadas populares pobres, com aparência grosseira e inculta. Mas uma das "missões" assumidas por Lima Barreto, em sua Literatura ${ }^{381}$,foi tentar ir além das aparências.

Há um episódio em Numa e a ninfa (NN), num ato de apoio a Neves Cogominho, que reúne explicitamente esses dois pólos da política republicana, mesmo que provocando algum mal-estar entre os socialmente privilegiados:

"A manifestação não chegava e aquela gente fina ansiava pela sua chegada e a sua dissolução, para que ficassem à vontade, longe da presença daqueles vagabundos que deviam compô-la."

(NN, p. 123).

em Teoria Literária, defendida no IEL/UNICAMP. Campinas, digitado, 2001; BOTELHO, Denílson - A pátria que quisera ter era um mito. Rio de Janeiro: Secretaria Municipal de Cultura, 2002; FREIRE, Zélia Nolasco - Lima Barreto, imagem e linguagem. São Paulo: Annablume, 2005.

${ }^{380}$ ANTONIO, João - Calvário e porres do pingente Afonso Henriques de Lima Barreto. Rio de Janeiro: Civilização Brasileira, 1977; LINS, Osman - Lima Barreto e o espaço romanesco. São Paulo: Ática, 1976. O ensaio de Lins foi, originalmente, sua tese de doutorado em Letras, defendida na Faculdade de Filosofia e Letras de Marília, em 1973.

${ }^{381}$ O livro de Sevcenko atribui a Lima Barreto e Euclides da Cunha a identidade de "mosqueteiros" intelectuais, versão republicana brasileira do papel combativo do intelectual moderno, exemplificado, na França, por Émile Zola. Vale lembrar que Lima Barreto problematizou, de maneira complexa e diferenciada, o intelectual missionário republicano ao menos em dois personagens: Policarpo Quaresma, em Triste fim de Policarpo Quaresma, e Inácio Costa, em Numa e a ninfa. E o desfecho do primeiro romance sugeriu intelectuais inesperados: Olga, filha de imigrante enriquecido, que enfrenta o marido doutor, em defesa de Policarpo; e Ricardo Coração dos Outros, mulato e poeta, amigo fiel de Quaresma. Não eram missões em abstrato, e sim esforços para afirmar identidades críticas naquele mundo. 
Já no apagar das luzes da manifestação, na grande casa daquele político, Lucrécio, "sorveu bem uma dezena de copos de cerveja" (Ibidem, p. 133). Cruzando numa das salas com o Senador Macieira, "poderoso político", Barba-de-Bode propôs "beber à saúde de Vossa Excelência”. Nem iniciada a fala,

"Veio-lhe um forte vômito e, antes que pudesse correr à janela, despejou-o ali mesmo, borrifando o peitilho do famoso senador e a barra das saias daquelas grandes damas. Lançou, lançou tudo o que tinha no estômago."

(Ibidem, p. 134).

O clima resultante foi de vexame e ridículo (embora políticos e damas impedissem que o chefe de polícia prendesse Lucrécio), enfatizando o fracasso desse homem e sua incapacidade de se igualar aos elegantes oradores daquele meio, tanto na fala (inaudível porque abafada pelo vômito) quanto nos modos (não conseguiu mínima privacidade para vomitar ${ }^{382}$ ). Ao mesmo tempo, Lucrécio expôs materialmente as entranhas às outras pessoas, através do vômito expelido, com resultados negativos para sua imagem, como se um monte de sujeiras, dele derivadas, conspurcasse um meio antes impecável, mostrando um conteúdo das entranhas que devia ser mantido sempre oculto. Mas não foi preso, e tudo continuou como antes: a limpeza não existia sem o detrito.

Tal passagem estabeleceu uma dupla articulação com o universo verbal.

Em primeiro lugar, no plano temático: tratava-se do uso da palavra no mundo político, instrumento de convencer, exibição de saberes e atestado de direito

${ }^{382}$ Saliba, a partir de outra série documental, identificou vida privada, na sociedade brasileira da república inicial, apenas na elite: "(...) ter uma vida privada era privilégio da elite brasileira que, a exemplo do Rio de Janeiro, se formava na maioria das cidades." (SALIBA, Elias Thomé - "A dimensão cômica da vida privada na república”. In SEVCENKO, Nicolau (Org.) - República: Da Belle époque à Era do Rádio. São Paulo: Cia. das Letras, 1998, pp. 289-365 (História da vida privada no Brasil — 3); trecho indicado na p. 318. A descrição, em Numa e a ninfa, dos bailes na Cidade Nova, sugere algo diferente: "Não é verdade, como fazem crer os panurgianos de 'revistas' e folbetins surannés, que os seus bailes sejam cousas licenciosas. Há neles até exagero de vigilância materna ou paterna, de preceitos, de regras costumeiras de grupo social inferior que realiza a criação ou a invenção de outro grupo." (NN, p. 85).

No romance Clara dos Anjos, a personagem que lhe deu título, jovem mulata pobre, foi seduzida e abandonada por um mimado rapaz de classe média, Cassi Jones. LIMA BARRETO, Afonso Henriques de - Clara dos Anjos. São Paulo: Brasiliense, 1956 (Obras de Lima Barreto - V) (1ª ed. 1923/1924).

Depois de ter sido desrespeitada pela mãe do rapaz, Clara disse, dirigindo-se à própria mãe: “- Nós não somos nada nesta vida." (CA, p.). Mais de que não possuir vida privada, a personagem surgiu como impossibilitada de ter essa experiência, num universo de relações sociais. 
e poder. Quem falava ocupava um espaço, debatendo, propondo, disputando. A palavra figurava como uma espécie de passaporte para os direitos e para ser igual, o que findava surgindo como privilégio de poucos. Destituído de fala, que o vômito impediu e mesmo substituiu, Lucrécio foi relegado ao mundo inferior dos diferentes, um pouco menos que um ser humano: animais não falam, exceto nas fábulas - quer dizer, na Literatura. E esse ser humano, que vomitou na hora de discursar, conduzia no apelido o nome de um animal — Bode —, como se não tivesse espírito ou este fosse menor que o dos demais.

Na primeira aparição de Lucrécio, para transmitir recado de Neves Cogominho a Numa, aquele homem respondeu a uma pergunta de Dona Edgarda, esposa do deputado e filha do governador:

"-Você sabe alguma coisa?

- Eu, minha senhora, não sei bem mas ouvi rosnar."

$(N N, p 60)$

Nesse trecho, a fala, no meio social de Lucrécio, foi designada por ele mesmo como ato de rosnar, algo menos que palavra articulada, som animalesco a que não faltava uma ponta de ameaça e irrazão.

A chegada daqueles manifestantes em apoio a Neves Cogominho também foi apresentada em metáfora zoológica:

“(...) e tudo parecia uma longa cobra fosforescente e musical que rastejava para o palacete."

(Ibidem, p. 129).

Nesse caso, é um animal ameaçador e selvagem, que rasteja rumo àquela moradia, num misto de força e submissão.

A fala de Canto Ribeiro, "renitente orador" e "empreiteiro de manifestações", foi assim caracterizada:

"A sua oratória era feita de berros, de mugidos e rugidos; (...)"

(NN, p. 129). 
Pouco depois daquela ocorrência, e ainda no desfecho da mesma comemoração, o imigrante russo Doutor Bogóloff — branco, pobre, amigo de Lucrécio e hóspede em sua casa durante boa parte do romance - aceitou uma carona do Doutor José Dias Chaveco, o chefe de polícia no Distrito Federal. Ao ser informado do apelido de Lucrécio, Chaveco riu e comentou:

\section{"-Bem posto... O cabra tem mesmo barba de bode!" 383}

Diante do nome de Bogóloff, a observação teve outra dimensão:

“-Ué! gentes! Que nome! É de santo?”

(Ibidem, p. 136/137).

Para o mulato pobre, o chefe de polícia evocou a animalidade ${ }^{384}$. Em relação ao pobre imigrante branco, o viés foi de coisa sagrada. Essa passagem lembra que não havia apenas o preconceito negativo contra negros e mestiços. Ele se complementava com o preconceito favorável em relação a brancos imigrantes (embora estes também fossem rejeitados, por exemplo, quando vistos genericamente como cáftens ou anarquistas — NN, p. 138), o que se observa também nas teorias sobre os benefícios raciais que a imigração européia traria para o Brasil ${ }^{385}$.

Em segundo lugar, mas não menos importante, no nível material da narrativa que se desenrola: qualquer romance é um reino da palavra, que apresenta seus personagens e lhes "registra" (ficcionalmente) falas. Engasgado pelo vômito,

383 O nome de Lucrécio é o mesmo do poeta romano da Antiguidade (cerca de 98 a 55 ac), que escreveu entre surtos de loucura e intuiu a existência de micro-organismos, causadores de doenças. Essa evocação clássica não figurou, de maneira explícita, no romance, ao contrário do que o Deputado Pieterzoon observou em relação a Numa: "O Numa ainda não ouviu a Ninfa; quando o fizer - ai de nós!" (NN, p. 26). A epígrafe do romance, extraída de Plutarco, também participou da identificação clássica: "(...) e esposo da ninfa Egéria, cumulado dos dons do seu amor, tornara-se, passando os dias junto dela, um homem feliz e sábio no conbecimento das cousas divinas." (Plutarco, Vida de Numa, em epígrafe de NN, p. 21)

${ }^{384}$ José Dias (ou Juca) Chaveco é o único personagem do romance que apresenta nível de fala matuto, à maneira de colunas em órgãos da Imprensa periódica brasileira desde o século XIX, como era o caso, na época em que Numa e a ninfa foi escrito, das "Cartas de um matuto" (SILVA, Marcos - Caricata república: Zé Povo e o Brasil. São Paulo: CNPq/Marco Zero, 1990).

385 SCHWARCZ, Lilia Moritz - "Nem preto nem branco, muito pelo contrário: cor e raça na intimidade”. In Idem (org.) - Contrastes da intimidade contemporânea. São Paulo: Cia. das Letras, 1998, pp. 173/243 (História da vida privada no Brasil — 4). 
Lucrécio apareceu como objeto do verbo, sem condições de dirigir seu destino nesse tecido da comunicação e dos poderes. O romancista que pretendesse ser "fiel à realidade" - caso de Lima Barreto, mesmo quando deformava caricaturalmente sua fisionomia - poderia, quando muito, "transcrever" (ficcionalmente) a condição daquele personagem, sem sofrer o influxo de sua argumentação (ficcional).

Política e literariamente, a perda da palavra reduziu Lucrécio à condição de objeto de outrem. O romance se diferenciava da arena política descrita ao expor criticamente essa triste situação para o pensamento do leitor. Se a política republicana brasileira excluía os "sem palavra", a Literatura crítica poderia iluminar-lhes a situação, usando outras palavras.

Cabe pensar sobre mais traços de Lucrécio Barba-de-Bode, em diálogo com diferentes personagens que o romance construiu, visando a entender a teia de relações sociais apresentada por Lima Barreto a respeito do exercício da fala naqueles pólos da política republicana e da narrativa romanesca.

Lucrécio era um mulato pobre, num Brasil muito racista. Quando o romance foi publicado (1915), o paradigma racial predominava na explicação do Brasil e de seu povo, com raras exceções - o próprio Lima Barreto e os ensaístas Manoel Bomfim e Alberto Torres eram algumas delas ${ }^{386}$. Em escritores de excepcional talento, como Sylvio Romero e Euclides da Cunha, aquele paradigma não impediu a valorização de experiências culturais populares muito complexas ${ }^{387} \mathrm{No}$ plano mais

${ }^{386}$ BOMFIM, Manoel - América Latina: Males de origem. Rio de Janeiro: Topbooks, 1998. (1 ${ }^{\mathrm{a}}$ ed. 1905); TORRES, Alberto - Problema nacional brasileiro. Brasília: UnB, 1982. (1 $1^{\text {a }}$ ed. 1914); Lilia Schwarcz faz um balanço das teorias racistas no Brasil e de suas transformações, a partir dos anos 20 e 30 do século xx, no ensaio, já indicado: SCHWARCZ, Lilia Moritz - "Nem preto nem branco, muito pelo contrário: cor e raça na intimidade", op. cit. Sobre Manoel Bomfim, consultar: SILVA, José Maria de Oliveira - Da Educação à Revolução: Radicalismo republicano em Manoel Bomfim. Dissertação de Mestrado em História Social, defendida na FFLCH/USP. São Paulo: digitado, 1991; Idem - "A questão racial na obra de Manoel Bomfim”. Caderno do CECH. Aracaju: UFS, 1: 29/35, Jan/Jun, 1992; BECHELLI, Ricardo Sequeira - Nacionalismos anti-racistas: Manoel Bomfim e Manuel Gonzalez Prada. Dissertação de Mestrado em História Social, defendida na FFLCH/USP. São Paulo: digitado, 2002. Bechelli comenta o anti-racismo de Manuel Gonzalez Prada (pensador peruano, contemporâneo de Bomfim) no artigo: Idem - "A Guerra do Pacífico (1879/1883) e o pensamento anti-racista de Manuel Gonzalez Prada". Projeto História (Dossiê "Américas"). São Paulo: PUC/SP, 31: 359/374, Dez 2005. A respeito de Alberto Torres, ler: MARSON, Adalberto - A ideologia nacionalista de Alberto Torres. São Paulo: Duas Cidades, 1975.

${ }^{387}$ ROMERO, Sylvio - Cantos populares do Brasil. Edição anotada por Luís da Câmara Cascudo. Rio de Janeiro: José Olympio, 1954. (1 $1^{a}$ ed. 1883); CUNHA, Euclides da - Os Sertões. Edição crítica por Walnice Nogueira Galvão. São Paulo: Ática, 2000. (1 $1^{\mathrm{a}}$ ed. 1902). Um bom estudo recente sobre esses dois pensadores, que também discute Gilberto Freyre e Câmara Cascudo, è Souza, Ricardo Luiz de. Identidade Nacional e Modernização na Historiografia brasileira: O diálogo entre Romero, Euclides, Cascudo e Freyre. Tese de Doutoramento em História, defendida na FAFICH/UFMG. Belo Horizonte: digitado, 2006. 
corriqueiro da ideologia, entretanto, ele se manifestou como preconceito puro e simples, violentamente excludente, um dos focos onde o autoritarismo se engendrava ${ }^{388}$.

A identidade mulata de Lucrécio pode ser comparada à configuração do personagem caricatural Zé Povo, produzido por vários desenhistas na Imprensa periódica brasileira daquela época. Criado no Brasil pelo artista português Bordalo Pinheiro, nos anos 70 do século XIX, ele se manteve em muitos órgãos da Imprensa nacional (principalmente, carioca), nas três décadas iniciais do período republicano, como uma espécie de síntese do homem comum, que refletia sobre sua situação na vida política e social do País.

A faceta crítica em relação à política republicana brasileira tornou-se uma importante característica de Zé Povo. Através dele, o povo, que deveria ser a razão de ser da República (literalmente: res publica, coisa do povo), aparecia como vítima do regime, carente de ações que o governo não desenvolvia, nas áreas de Educação, Saúde e Moradia, espoliado pela cobrança de impostos, vendo o dinheiro assim arrecadado ser gasto indevidamente, para o consumo de seres inúteis: os políticos. Um resumo desse estado de coisas foi definir Zé Povo como vítima da política republicana no Brasil ${ }^{389}$.

Convivendo com dimensões do monarquismo e do radicalismo republicano ${ }^{390}$, essas críticas de Caricatura (Zé Povo) e Literatura (Lucrécio Barba-de-Bode) evidenciam um clima de reflexão sobre o que era República, o que era povo, quais as potencialidades do regime e sua realidade cotidiana naquele Brasil. Contemporâneo de debates sobre identidade nacional e raça, o personagem caricatural tornava visível um povo que, como arquétipo, se transfigurava em diferentes cores (branco, negro e, mais freqüentemente, mulato) e níveis sociais

\footnotetext{
${ }^{388}$ Werneck Sodré identificou esse preconceito a ideologia, sem explorar suas tensões. SODRÉ, Nelson Werneck - A Ideologia do Colonialismo. Seus reflexos no pensamento brasileiro. $2^{\mathrm{a}}$ ed. Rio de Janeiro: Civilização Brasileira, 1965 (1 $1^{a}$ ed. 1961). Sobre o caráter autoritário do preconceito, com ênfase no anti-semitismo, ver: ARENDT, Hannah - Origens do Totalitarismo. Tradução de Roberto Raposo. São Paulo: Cia. das Letras, 2004.

389 Retomo, sobre Zé Povo, questões discutidas em: SILVA, Marcos - Humor e política na Imprensa: Os olhos de Zé Povo. Dissertação de Mestrado em História Social, defendida na FFLCH/ USP. São Paulo: datiloscrito, 1981. Uma versão resumida desse estudo foi publicada em livro: Idem, Caricata república: Zé Povo e o Brasil, op. cit.

390 JANOTTI, Maria de Lourdes Mônaco - Os subversivos da República. São Paulo: Brasiliense, 1986; QUEIROZ, Suely Robles de - Os radicais da República: Jacobinismo: Ideologia e ação. São Paulo: Brasiliense, 1986.
} 
(proprietário, homem de classe média e, mais habitualmente, muito pobre), unificados pela exploração que sofriam por parte do estado e da política. Ao mesmo tempo, as críticas de Zé Povo participavam de uma definição de cidadania e legalidade, avessa a práticas reivindicatórias do período - revoltas e outras manifestações de rua - receosa de que Zé Povo se tornasse um valentão a serviço de poderosos.

Em Lucrécio Barba-de-Bode, todavia, ser mulato transcendia a condição de síntese do Brasil, para atingir um viés ainda mais trágico. Tratava-se de pertencer ao mundo dos excluídos por raça e pobreza. E excluídos que assumiam uma identidade ambígua, nem preto nem branco, que viviam o pior de qualquer condição. Essa exclusão se desdobrava em ser eventualmente incluído de maneira degradada, ou mesmo auto-destrutiva, naquela sociedade: o exercício da violência, sob risco permanente.

Uma evidência desses perigos foi exemplificada na notícia sobre a morte de Zeca Boneco, "antigo aprendiz de marceneiro" (outro Lucrécio! NN, p. 175), transmitida por Barba-de-Bode e comentada pelo narrador do romance:

“- Um rapaz... Um rapaz dos nossos... amigo do Totonho...

- Quem foi?

- Opovo!

Barba-de-Bode pronunciou esta palavra e respirou aliviado; (...)."

(Ibidem, p. 175).

Nessa passagem, fica patente que Lucrécio é multidão. Ao mesmo tempo, a narrativa introduziu uma sutil diferença entre os servidores dos políticos dominantes, gente que "fazia parte da política, e tinha o papel de ligá-la às classes populares" (NN, pp. 58/59), e um outro povo, capaz de não aceitar arbitrariedades e até de linchar seus algozes menores. Nesse sentido, o poder popular ainda sobrevivia, como potência, embora reagindo num nível apenas imediato - o justiçamento de um opressor secundário.

$\mathrm{Na}$ primeira vez em que o romance apresenta Lucrécio em casa (capítulo III), há um forte episódio sobre a dimensão trágica de sua condição. Na hora de almoçar, ele pediu arroz à mulher, que não fizera esse prato e declarou sua falta na casa. Lucrécio se dirigiu, então, ao filho: 
“- Lúcio, vai lá à venda e diz ao 'Seu' Antunes que mande um quilo de arroz, Ângela, ajuntou, dá o caderno.

o pequeno ficou enleado e, embora se houvesse erguido, não moveu o pé; a mulher fez que não ouvia. Barba-de-Bode insistiu com fúria:

- Você não vai, rapaz? Não está ouvindo?

A mãe interveio:

- Sente-se aî!

- Como? Fez o pai.

— Então você não sabe que o Antunes não nos fia mais?

- Porque?

- Ora, porque? Porque você não lhe paga e não estou para o pequeno estar ouvindo desaforos!

Lucrécio ergueu-se, com olhos fora das órbitas, rilhando os dentes e expectorou:

— Aquele... Ele me paga!

E dirigiu-se para o corredor; a mulher interveio:

- Que vai você fazer, Lucrécio? Você deve...

- Deixe-me! Disse ele.

A mulher insistiu:

— Não vá lá... Você tem um filho, homem de Deus!

Desvencilhou-se da mulher; ela, porém, ainda o deteve na sala de visitas, quase chorando:

— Não vá lá, Lucrécio! - Não vá!

- Deixe-me! Deixe-me! Vocês não sabem o que é ser mulato! Ora bolas!"

(NN, pp. 89/90).

Esse fragmento do romance se organizou em torno da comida (o arroz desejado e inexistente) e da situação de Lucrécio no cotidiano daquela comunidade (devedor, sem crédito na venda). Informado sobre o que ocorria, ele teve um momento de fúria. E então, "com olhos fora das órbitas, rilhando os dentes", "expectorou" (grifo meu): - Aquele... Ele me paga!"

O romancista usou o verbo "expectorar" para definir a fala raivosa de Lucrécio. Suas palavras furiosas foram apresentadas, portanto, como escarro. 
A mesma matéria figurara no romance, antes, num contexto social muito diferente. Quando o deputado Numa mudara para a suntuosa moradia pertencente à família do sogro, no bairro carioca de Botafogo,

\section{"(...) o que o aborrecia muito era a falta de escarradeiras."}

Ibidem, p. 50 .

Também em relação ao orador Canto Ribeiro, o verbo expectorar serviu para designar discurso:

"Durante vinte minutos, expectorou as mais sórdidas banalidades sobre a república e a pátria."

(NN, p. 130)

Mas o "catarro" de Lucrécio não buscava vasilhas de porcelana para se abrigar nem expressava florilégios retóricos. Lançado numa hora em que sentia ódio e revolta, ele evidenciava, metaforicamente, uma elaboração orgânica de defesa contra a doença da humilhante inferiorização. E o personagem sintetizou o que sofria ou podia fazer numa só força, misto de ressentimento e ameaça: ser mulato.

A intensidade da reação de Lucrécio — que culminou na menção à identidade racial como mágoa e trunfo - relembra, ao leitor, uma história do ser mulato nas condições de memória e também potência. Onde ele aplicava esse poder virtual?

O trecho referido é um exemplo dos lugares e instantes usados para tal fim: em rusgas cotidianas, com a mulher, com credores. Noutros momentos, fica evidente que a mesma força era empregada a serviço de seus superiores da política. Mas era um uso vão e auto-destrutivo. Em passagem anterior do romance, a voz narrativa informara ao leitor que Lucrécio fora carpinteiro, ofício abandonado depois que se envolveu com os negócios da política, com seu mundo de contravenções e crimes até matar um desafeto (NN, p. 59). Num trecho já próximo do final da obra, a mulher de Lucrécio, Ângela, refletiu, através da voz narrativa principal, sobre

"(...) a maneira injusta que (Barba-de-Bode) empregava a sua bravura"

(Ibidem, p. 245). 
A política republicana figura no livro, através de Lucrécio Barba-de-Bode e seus iguais, como instrumento para degradar os pobres, e não para sua expressão no espaço público. Durante a manifestação de apoio a Neves Cogominho, o narrador concluíra mesmo:

"Vendo essa gente miserável, degradada física e moralmente, tão contente com a política, parecia que ela não tinha por fim fazer os povos felizes..."

(NN, p. 130)

Fazer política, para Lucrécio, era perder uma identidade de origem (trabalhador, ligado a seus companheiros de ofício, produtor de coisas e também produtor de si) e se perder num mundo imediato, sem passado nem futuro, sequer para o filho, como se observa noutra passagem, que antecede a disputa pelo arroz:

"O pai viu ainda os olhos luminosos da criança, carbunculando nas escleróticas muito brancas, e pensou de si para si: que vai ser dele? Lembrou-se de dar-lhe dinheiro para os sapatos com que fosse à escola, mas estava atrasado na casa. A desordem de sua vida; antigamente... Que vai ser dele? Bem, arranjaria um emprego, fa-lo-ia estudar e havia de tomar caminho. Que vai ser dele/ E logo the veio o ceptismo desesperado dos imprevidentes, dos apaixonados e dos que erraram; há de ser como os outros, como eu e muita gente. É sina!"

(Ibidem, p. 89).

Trata-se de um instante de angústia, sucedido pela angústia ainda maior do frustrado querer comer arroz e da consciência de ser mulato. Fome insatisfeita e potencialidade truncada: o sofrido corpo e o esgarçado espírito de Lucrécio se apresentaram num impossível processo de afirmação, sem chances de sucesso. O fracasso pessoal se configurou, no romance, como fracasso de uma sociedade e de seu sistema político. A própria violência exercida por Lucrécio Barba-de-Bode se fez acompanhar das múltiplas violências experimentadas pelo personagem e por seus companheiros de infortúnio, num processo sem retorno, malgrado os "olhos luminosos" de seu rebento.

Lucrécio teve força política para recomendar o Doutor Bogóloff e o Engenheiro Doutor Gama Silveira (ambos brancos) junto a poderosos chefes republicanos, 
que lhes garantiram empregos destacados, mas terminou o romance dependendo dos mesmos expedientes perigosos e de ganhos esporádicos para sobreviver, conformado:

"Quem não tem habilitações tem que esperar."

(NN, p. 248).

O romance nos lembra que, sem a espera dos Lucrécios, o poder dos habilitados não existiria. E deixara claro, bem antes, que a manutenção do personagem como "encostado" ("agente da polícia extra-numerário"), dependendo dos poderosos, era muito útil para estes:

"Ai, ele podia com mais liberdade prestar-lhes os seus serviços de popular e, sendo lugar provisório, não the viria uma frouxidão inqualificável no seu entusiasmo pelas altas qualidades administrativas deles."

(Ibidem, p. 144).

O esforço de Barba-de-Bode para ascender socialmente, através dos expedientes políticos, foi infrutífero, o que não se verificou, todavia, em relação a dois outros personagens da narrativa: o próprio Numa Pompílio de Castro e Grégory Petróvitch Bogóloff.

Os dois eram doutores e brancos.

Na primeira aparição de Bogóloff, foi lembrada uma conversa dele com um compatriota e intérprete no Brasil:

“-És tolo, Bogóloff; devias ter-te feito tratar por doutor.

- De que serve isso?

- Aqui, muito! No Brasil, é um título que dá todos os direitos, toda a consideração... Se te fizesses chamar de doutor, terias um lote melhor, melhores feramentas e sementes. Louro, doutor e estrangeiro, ias longe! Os filósofos do país se encarregavam disso."

(NN, pp. 91/92). 
Quando alcançou sucesso como orador na Câmara de Deputados, Numa relembrou a juventude pobre, na casa paterna, e concluiu:

"Muito pode a formatura! Se ele não se fizesse doutor, que seria?..."

(Ibidem, p. 42).

Para Numa, o tornar-se doutor foi opção deliberada pela conquista de privilégios. Embora de origem humilde, esse personagem procurou, na formação acadêmica, uma chave para o sucesso social.

"Viu a formatura, o doutorado isto é, ser um dos brâmanes privilegiados, dominando sem grande luta e provas de valor, pois, com ele, afastava uma grande parte dos concorrentes."

(...)

No seu entender, o máximo escopo da vida era formar-se e formou-se com grande esforço e tenacidade."

(NN, pp. 30 e 31).

"Desde menino, sentira bem que era preciso não perder de vista a submissão aos grandes do dia, adquirir distinções rápidas, formaturas, cargos, títulos, de forma a ir se extremando bem etiquetado, doutor, sócio de qualquer instituto, acadêmico ou cousa que o valha, da massa anônima."

(Ibidem, p. 117).

Nessa busca, os saberes assumiram um caráter estritamente funcional, sem qualquer valor intrínseco, adquirindo, pelo contrário, um aspecto mecanicista e imediato - superar exames, conquistar novos degraus de carreira (promotor, juiz, chefe de polícia, deputado estadual, deputado federal). Tanto os livros quantos os conteúdos de discursos não despertavam entusiasmo em Numa, mas lhe serviam de ornamentos sociais, compondo uma imagem pública de homem sério, estudioso, culto, e foram instrumentos para seu sucesso.

Casar-se com a filha de um governador e fazer carreira política se constituíram noutros desdobramentos desse trajeto. 
"Com toda a firmeza, com aquela firmeza que empregou para formar-se, Numa tratou de casar-se com a filha de Cogominho e não viu diante dele obstáculo algum, como aquele não vira quando tratou de casar-se com a filha do capitalista Gomes."

(NN, p. 35).

Ao lembrar o exemplo do casamento de Neves Cogominho, Lima Barreto deixou claro um padrão habitual nesse meio para a ascensão social e a carreira política.

Embora o romance não tenha registrado conflitos maiores entre Numa e sua mulher, ele também não indicou profundos afetos de um com o outro. Descrições de abraços e beijos mais intensos foram monopólio dos encontros entre Edgarda e seu primo e amante, Benevenuto:

"E os dois se beijaram longa e fartamente."

(Ibidem, p. 114.)

O amor, portanto, não fazia parte dos compromissos entre Numa e a esposa. Em contrapartida, a colaboração da última no preparo dos discursos do deputado - mais que colaboração, um verdadeiro trabalho de ghost writer - e sua companhia na fruição do sucesso alcançado pelo marido evidenciaram os intensos laços sociais que os dois possuíam. Apesar de Edgarda parecer realmente ligada, no plano amoroso, a Benevenuto, sua vitrine social, na Rua do Ouvidor (desfile triunfante, após o sucesso de Numa como orador: NN, p. 28) e noutros espaços de elite, era em companhia do marido deputado.

A ausência de paixão serviu também para caracterizar a política, na abertura do romance, definindo aquele momento histórico como surpreendente exceção à regra:

"O grande debate que provocara na Câmara o projeto de formação de um novo Estada na Federação Nacional apaixonou não só a opinião pública, mas também (é extraordinário!) os profissionais da política."

(NN, p. 23).

Era outra paixão utilitária: perspectiva de "cargos políticos e administrativos" (Ibidem), preocupações partidárias, novos grandes negócios... 
Numa começou a discursar na Câmara de deputados por insistência de Edgarda, insatisfeita com a imagem pública apagada do marido. Apesar do sucesso como orador, o romance não deixou de caracterizá-lo na condição de medíocre portador de voz postiça (orador de segunda mão), marcado pelo conformismo em relação a tudo para continuar na posição social que alcançara, ou até ir além dela. Diante dos impasses que o crescimento de Bentes como candidato à presidência trouxera, ele concluiu:

"Só havia um alvitre; ir para fora e esperar que as coisas se decidissem, aderindo, então, ao vencedor. Seria bom."

(Ibidem, p. 63).

No desfecho do romance, descobrindo que a mulher tinha por amante Benevenuto e que este era o verdadeiro redator de "seus" discursos (sabendo-se, portanto, orador de terceira mão),

“(...) Numa voltou, vagarosamente, pé ante pé, para o leito, onde sempre dormiu tranqüilamente."

(NN, p. 265).

Tanto no situacionismo radical quanto nesse convívio com a traição da esposa — dificílimo, para os padrões morais da época - , Numa deixou claro que qualquer preço era válido para se manter naquele mundo de privilégios, desde que sua voz (mesmo que de terceira mão) fosse garantida.

Um tenso contraste com essa falta de perspectivas maiores foi estabelecido no contato visual e físico do deputado com uma estatueta decorativa, em sua casa:

“(..) examinou os bibelots e demorou-se a considerar uma estatueta de bronze. Sentada em êxedra, de mármore, uma mulher tinha os braços abertos sobre os ramos da cadeira. O busto estava nu, a parte inferior coberta, e, aos pés, uma coroa de louros. Viu-lhe o olhar perscrutador, a expressão do rosto de serena imaterialidade, a atitude geral de suspensão.

(...)

Teve medo de apanhá-la; afinal, o fez. Leu alguma coisa na base; não 
decifrou bem ou não teve confiança na leitura. (...) Trouxe-a bem junto à janela e leu claramente? Histoire - História!"

(Ibidem, pp. 51/52).

Era um objeto pequeno, capaz de prender a atenção de Numa com sua postura física e talvez ética. As referências clássicas (coroa de louros, busto nu) e a nobreza de materiais (bronze, mármore) contribuíram para aumentar-lhe a gravidade, como se vigiasse aquele mundo, embora sem poder para alterar seus termos - a estatueta apareceu no romance durante visita do empresário e jornalista Fuas Bandeira ao deputado, para tratar de negócios políticos que poderiam ser muito lucrativos para as partes envolvidas ${ }^{391}$. A História estava ali, indagadora, mas frágil. Numa não a ignorava, mas também não a incorporava plenamente. Mas o caráter perturbador da estatueta ainda mantinha uma pequena esperança naquele mundo. Mesmo que o deputado e seus iguais não tomassem conhecimento dela, na maior parte do tempo, a História continuava a existir, sem perder traços de dignidade e beleza. Quem a retomaria (ou lhe daria vida) plenamente? Ou a História continuaria a ser apenas um pequeno objeto decorativo, entre outros, no mundo da riqueza?

Comentando o cuidado de Numa com a própria aparência, o romance evocou esse traço de sua personalidade desde a juventude pobre:

"Numa empregava o tempo fazendo lentamente a sua toilette de sair. Sempre a fizera com lentidão e vagar; desde os tempos de pobreza, que ele oficiava no vestir a calça, no abotoar os punhos e estudava bem ao espelho o atar a gravata."

$(N N, p .57)$

Tal zelo se articulava com outras dimensões do personagem e de seu meio. Ele configurava uma cultura do simulacro, que muito dificultava (ou mesmo impossibilitava) identificar os argumentos elevados de seus sujeitos às práticas

${ }^{391}$ Uma referência à escrita de Fuas Bandeira salientou o teor venal de seu papel: "Escrevia, mas escrevia como um guarda-liuros hábil." (NN, p. 46). Nessa afirmação, o ato de escrever na Imprensa foi identificado a função contábil, remetendo aos tráficos de influências por Política e Imprensa. Enquanto isso, um romance era escrito (o próprio Numa e a ninfa), pretendendo superar essa limitada função. 
e aos objetivos observados. Noutro exemplo, o governador Neves Cogominho se beneficiou de um episódio de caça (matou bezerro como se fosse onça) que lhe rendeu fama de valentia - Idem, p. 119. . romance tendeu a caracterizar esse universo de valores como mundo às avessas, onde as altas justificativas se reduziam às baixas finalidades - dinheiro, poder de mando, desprezo pelos socialmente inferiores.

O relacionamento amoroso de Edgarda com o primo Benevenuto foi insinuado para o leitor desde a primeira aparição desse último personagem:

"Numa, então, conheceu-o; tratou-o com a polida severidade de suas virtudes judiciárias e admirou-se da satisfação com que sua mulher o acolheu e do olhar doce e curioso com que o cobriu todo."

$(N N, p .37)$

Revelou-se plenamente, todavia, apenas na metade do romance (Ibidem, p. 109), em encontro dos dois.

Ao contrário de Numa, Edgarda lia muito, e extraía prazer desse ato, diferenciando-se, nesse aspecto, da cultura do simulacro (NN, p. 64). Seu interesse e sua vocação política eram muito intensos, mesmo sem ter direitos plenos de cidadania, uma vez que as mulheres não eram eleitoras nem podiam ser eleitas nessa época, tanto no Brasil quanto noutras partes do mundo. A interferência de Edgarda se manifestou tanto na elaboração daqueles discursos quanto em conversas com o marido sobre temas da vida política (um projeto de estrada de ferro, por exemplo - Ibidem, p. 57). Critérios de Justiça povoavam seus argumentos, como na atitude contra conceder pensão à viúva de Lopo Xavier (NN, p. 68). Uma matizada visão da cidade e de suas diferenças sociais, construída durante viagem de bonde para Santa Teresa (visita ao senador Macieira e, em seguida, encontro amoroso com Benevenuto - Ibidem, p. 96), pareceu derivar do pensamento de Edgarda.

A mulher de Numa pertencia à elite social. Considerá-la "excluída" seria um exagero, embora algumas práticas políticas fossem inacessíveis às mulheres. Ao fazer ressoar uma voz oculta (suposta autoria dos discursos, conselhos e opiniões sobre o trajeto político do marido, preocupações com o pai), ela exemplificava um estilo de vida feminino de elite, manifestando talentos 
e potencialidades. Edgarda tanto demonstrava uma percepção de problemas sociais e políticos (em diálogo com Dona Celeste, mulher de Macieira, Edgarda argumentou que "(...) eles (os políticos) devem ouvir todo o mundo, para bem representar a vontade do povo, por quem são eleitos." (Ibidem, p. 101), quanto se diferenciava de outras companheiras de gênero e classe social (visão da casa de Macieira como dotada de luxo sem gosto) (NN, p. 99).

No romance, Edgarda não desempenhava esse papel sozinha. Mme. Forfaible, "esposa do General do mesmo nome" (NN, p. 43), vivia mais a vida militar do esposo que ele próprio, "com o olhar de batalha que o marido não tinha" (Ibidem, p. 128). Como Edgarda, ela era mais forte que o marido, que nunca apareceu diretamente na trama. A viúva de Lopo Xavier cuidava da própria pensão e era tensa com militares (NN, p. 65). E a amante francesa de Macieira, Arlete, lembrava que a política era também negócio de prostitutas (Ibidem, pp. 151-153).

O nome de Mme. Forfaible sugere um trocadilho, em francês: Forte/Faible, forte/fraca. É uma síntese expressiva dessa situação feminina de elite, à margem de direitos políticos formais, mas muito influentes nesse meio.

Tais margens de manobra eram ocupadas pelas mulheres privilegiadas socialmente, que, inclusive, tinham amantes — Edgarda, Alice (mãe de Macieira). As pobres, quando muito, contemplavam os amores alheios (as costureiras que moravam na casa onde Edgarda se encontrava com Benevenuto) ou vivenciavam suas próprias desditas (a mulher de Lucrécio - Ângela). Nelas, o espectro da exclusão de gênero se duplicava na exclusão social e racial.

A preocupação com os lugares ocupados pelas mulheres na sociedade brasileira se fez presente $m$ outras obras de Lima Barreto, como se observa na Olga, do Triste fim de Policarpo Quaresma (potencialidade intelectual, senso de justiça, lealdade), e na Clara dos Anjos, do romance que tomou-lhe o nome para título (beleza e vitalidade corrompidas pelo desrespeito alheio) ${ }^{392}$. Tratava-se de grande tema, problematizado na Literatura desde meados do século xix, no plano internacional (a Ana Karênina, do romancista russo Leon Tolstoi, no romance homônimo, e a Nora, do dramaturgo norueguês Henrik Ibsen, na peça Casa de bonecas, dentre tantas outras), bem como na Literatura brasileira

\footnotetext{
392 BARRETO, Afonso Henriques de Lima - Triste fim de Policarpo Quaresma, op. cit.; Idem, Clara dos Anjos, op. cit.
} 
(a Aurélia, de José de Alencar, no romance Senhora, e a Capitu, de Machado de Assis, no romance Dom Casmurro, por exemplo) ${ }^{393}$.

Em Numa e a ninfa, as mulheres de elite surgiram como sujeitos ativos, dotados de poderes, que não eram alheios aos preconceitos de classe, chegando ao limite de desprezo pelo povo ou, quando muito, à tolerância em relação a sua inevitável existência:

"- Eu, acudiu a mulher de Numa, não os aborreço nem os estimo; suporto-os e acho-os necessários."

(NN, pp. 124/125).

Outras personagens foram mais longe nesse desdém pelo universo popular, casos de Mme. Forfaible ("Que tem o senhor com o povo? O povo não vale nada..." - dirigindo-se a Numa, Ibidem, p. 182) e de Mme. Costale, mulher do político Xandu ("Mandava tudo para o Acre." — NN, p. 125). No último caso, a distância se mesclou a um universo de selvageria, associado àquela gente.

Certamente, essas posturas não eram exclusivas das mulheres, podiam ser observadas em fala do jornalista Fuas Bandeira, dirigida ao deputado Numa:

“- O povo! O povo! Que tem o povo com estas questões? Por acaso ele pode raciocinar sobre finanças? Creio que não, meu caro doutor. Não é a sua opinião?"

(Ibidem, p. 53).

Enquanto essa pergunta era feita, o leitor tomava conhecimento do refinado raciocínio de Fuas Bandeiras sobre finanças, que beneficiava com fundos públicos seus interesses privados.

Em sentido similar, a descrição do ato de apoio a Neves Cogominho incluiu a presença de

393 TOLSTOI, Leon - Ana Karênina. Tradução de João Gaspar Simões. São Paulo: Abril, 1971. ( $1^{a}$ ed. 1877); IBSEN, Henrik - Casa de Bonecas. Tradução de Maria Cristina Guimarães Aranyi. Mairiporã: Veredas, 1990. (1ª ed. 1897); ALENCAR, José de - Senhora. São Paulo: Moderna, 1991. (1 $1^{a}$ ed. 1875); ASSIS, Joaquim Maria Machado de - Dom Casmurro. Rio de Janeiro: Civilização Brasileira, 1977. (1ª ed. 1900). 
“(..) moços limpos: estudantes, pequenos empregados, aspirantes a empregos — gente iludida com promessas de lugares e promoções”

(NN, p. 129).

A contrapartida dessa designação foi considerar os demais participantes sujos, incontornável sujeira do Brasil, como o vômito de Lucrécio.

Uma caracterização da Câmara de Deputados, atribuída ao jornal O Intransigente, correspondeu especularmente a esse desprezo da elite política e social pelas camadas populares, apequenando fortemente aquela instituição como

\section{"(..) indecente valhacouto de caixeiros de oligarcas abandalhados"}

(NN, p. 27).

O romance cuidou de fundamentar essa avaliação através de seus personagens centrais, sem esconder uma dose de angústia diante da República opressiva e corrupta, voltada para a satisfação dos interesses privados da elite brasileira. Embora algumas observações de diferentes protagonistas sugiram potencialidades críticas de irem além daqueles limites (Bogóloff, Edgarda, Benevenuto), o livro evitou idealizar esse universo do dificilmente possível.

O exemplo de Bogóloff, pobre imigrante que conseguiu ascender socialmente, atestou a grande vantagem de ser branco e europeu, portador de um grau universitário, mesmo que num campo de saber (Línguas Orientais) pouco prático para as funções que assumiu. Sua nomeação para o cargo de Diretor da Pecuária Nacional passou pela apresentação de projetos sobre a produção de animais domésticos gigantes, com um boi valendo por quatro (Ibidem, pp. 158 e 161) e a criação de peixes em seco (NN, p. 164). Ao mesmo tempo em que esses argumentos sobre uma fauna fantasiosa pareciam fábulas, Bogóloff apelava para o argumento da Ciência:

"Lido com as últimas descobertas da ciência e a ciência é infalivel."

(Ibidem, p. 163).

O que estav em jogo, nesse personagem, era a renúncia a um projeto de trabalho regular (a colônia de imigrantes, o plantio de diferentes gêneros) e a adesão 
ao universo do simulacro político, com resultados efetivos no plano exclusivo do sucesso privado. O argumento da ciência como última palavra também figurou nas falas positivistas de Inácio Costa, em defesa da ditadura republicana (NN, pp. 76/77), embora seu discurso empolado e cheio de referências filosóficas, na manifestação de apoio a Neves Cogominho, tenha merecido desprezo do público ali presente, expresso em "pigarros indiscretos" (Ibidem, p. 131).

Esse compromisso entre potenciais e adesão à mediocridade, com a chancela do público, esteve presente também em Albuquerque,

“(...) só poeta nas salas, só conferencista nas salas, teimoso em sê-lo em toda parte, mas mesmo os que o conheciam nos salões, não admitiam que o fosse fora deles.".

"(..) poeta de salas e festas burguesas."

(NN, pp. 73 e 74).

A narração evitou atribuir maior talento a esse escritor, verdadeiro literato missionário dos salões. Sua caracterização negativa, todavia, também serviu para lembrar que a Poesia (ou a Literatura em geral) poderia muito mais se conseguisse ultrapassar uma barreira espacial e social semelhante àquela que prendia Albuquerque.

Em sentido paralelo, a palavra ornamental e oca também caracterizou um debate poliglota na Câmara de Deputados, onde o papel principal da palavra, ao invés de expressar alguma proposta efetiva, era silenciar o orador (Ibidem, pp. 259/261) e não ser compreendida pelos ouvintes.

As duas situações (poesia privada de salão e retórica da incomunicabilidade no espaço público) sublinharam os compromissos da palavra institucionalizada com o silenciamento e a preservação daquele estado de coisas. O lamento de Alfredo Bosi em relação aos limites de Lima Barreto, escritor que ele caracterizou como talentoso portador de um conteúdo em busca de uma forma, concomitante à forma em busca de conteúdo própria a Coelho Neto, revela-se pouco frutífero ${ }^{394}$. O autor de Numa e a ninfa procurava fugir da reluzente forma, sem que isso significasse um simples projeto ideológico (missão) destituído de fazer

${ }^{394}$ BOSI, Alfredo - "As Letras na Primeira República”. In op. cit. 
literário. Criticar aquela sociedade também era criticar a Literatura que ela pretendera reduzir a um leve sorriso, ou a uma inabalável beleza. Contra isso, era possível procurar risos contaminados pela angústia e belezas inesperadas ou, até sua exposição, impedidas.

O vômito de Lucrécio Barba-de-Bode, perturbadora sujeira naquele ambiente tão refinado, resultou do excesso de comida e bebida ingeridas na manifestação de apoio a Neves Cogominho pelo personagem. Seu exagero e sua pressa no comer e no beber se justificavam pelas carências cotidianas, expressas escancaradamente no episódio do arroz desejado e inexistente. Ao mesmo tempo, eram alimento e bebida provenientes daquele requintado meio que, vomitando, ele sujava.

Vomitar era devolver ao mesmo mundo, num instante de descontrole físico e psicológico, matérias que, no plano físico e no plano metafórico, dele procederam. Para todas as partes envolvidas, tratava-se de uma hora da verdade.

Involuntariamente, e pela única vez, irmanavam-se. 